\title{
Distribution of endocrine disruptors in the Mondego River estuary, Portugal
}

\author{
Cláudia Ribeiro • Miguel Ângelo Pardal • \\ Filipe Martinho • Rui Margalho • \\ Maria Elizabeth Tiritan • Eduardo Rocha • \\ Maria João Rocha
}

Received: 10 August 2007 / Accepted: 14 January 2008

(C) Springer Science + Business Media B.V. 2008

\begin{abstract}
Recent studies in the Mondego River estuary demonstrated signs of pollution in the area, but the nature of the contamination remains unexplored. Because there seems to be any studies in that zone checking for the simultaneous presence of xenoestrogenic endocrine disrupting compounds, either of animal (estradiol and estrone), vegetal (daidzein, genistein and biochanin A), pharmaceutical (17 $\alpha$-ethynylestradiol) or industrial (bisphenol A, 4octylphenol, 4-nonylphenol) origins, the main objective of this study was to investigate their presence, in every year season and at eight points along the estuarine gradient. For this propose, water samples $(2 \mathrm{~L})$ were collected in high and low tides, precon-
\end{abstract}

C. Ribeiro · M. E. Tiritan • M. J. Rocha

Superior Institute of Health Sciences - North (ISCS-N), Gandra, Paredes, Portugal

C. Ribeiro $\cdot$ E. Rocha $\cdot$ M. J. Rocha

Interdisciplinary Centre for Marine and Environmental

Research (CIIMAR),

Porto, Portugal

C. Ribeiro $\cdot$ E. Rocha $\cdot$ M. J. Rocha

CIMAR Associate Laboratory,

University of Porto,

Porto, Portugal

C. Ribeiro $\cdot$ M. E. Tiritan

Centre of Studies of Organic Chemistry,

Phytochemistry and Pharmacology of the

University of Porto (CEQOFFUP),

Porto, Portugal centrated in the Oasis HLB cartridges and cleaned in silica cartridges before their analysis by HPLC-DAD and GC-MS. The current data showed the absence of contamination by animal or pharmaceutical estrogens and by alkylphenols, but demonstrated the presence of high levels of phytoestrogens (up to $1.1 \mu \mathrm{g} / \mathrm{L}$ ) and of bisphenol A (up to $880.0 \mathrm{ng} / \mathrm{L}$ ). Because these two chemicals existed in high environmental concentrations in the most upstream sampling station, and taking in account that these pollutants may additively contribute to endocrine disruption, namely on fish, it was concluded that at least this particularly area of the Mondego estuary deserves continuous monitoring programmes.

\section{Ribeiro $\cdot$ E. Rocha}

Institute of Biomedical Sciences Abel Salazar (ICBAS),

University of Porto,

Porto, Portugal

M. Â. Pardal · F. Martinho · R. Margalho

IMAR - Institute of Marine Research,

Department of Zoology, University of Coimbra,

Coimbra, Portugal

M. J. Rocha $(\bowtie)$

Department of Pharmaceutical Sciences,

Superior Institute of Health Sciences (ISCS-N),

Rua Central de Gandra 1317,

4585-116 Gandra, PRD, Portugal

e-mail: mjsrocha@netcabo.pt 
Keywords Mondego estuary · Endocrine disrupting chemicals (EDCs) - Bisphenol-A · Genistein .

Biochanin-A $\cdot$ Daidzein

\section{Introduction}

The Mondego River flows from the highest continental mountain of Portugal (Serra da Estrela) to the Atlantic Ocean. During its course of $227 \mathrm{~km}$, it runs through rural as well as highly urbanized and industrialized areas before reaching its 1,600 ha estuary, where it becomes visible polluted (Ferreira et al. 2004). Its main pollution sources are waste waters, most coming from several sewage treatment plants that give support to approximately 200,000 inhabitants and to different types of industries, and the agricultural run-off, end result of 15,000 ha of cultivated land (mostly rice and corn fields) located upstream the Mondego estuary (Ferreira et al. 2004). Currently, it is known that the contamination of this estuary increased during the last decade because several pollution indicators have been referred for this area, such as the increase of eutrophication (Lopes et al. 2000; Ferreira et al. 2004) and the decrease of aquatic biodiversity (Cardoso et al. 2004). Also, the continuous increase of cutaneous diseases in fish, and sometimes in humans, by mucormycosis, was somehow related to the increase of pollution in this estuary (Coelho et al. 2003). In fact, the opportunistic funguses, which are common in river waters, become pathogenic when the water is highly polluted, either by vegetal decomposing matter and/or by faecal contamination (Arvanitidou et al. 2005). In addition, several authors described the presence of liver lesions in fish caught in the Mondego estuary (Santos et al. 2002), which, can be induced, among other factors, by high levels of inorganic compounds, polychlorinated biphenyls (PCBs) and organotins (Fossi et al. 2004); all found in this area (Diez et al. 2005; Pereira et al. 2005). Other compounds, such as estrogens or estrogen mimics (alkylphenols, phytoestrogens, etc.), which apparently were never investigated in this region, can contribute for diverse fish ailments. Those chemicals, designed herein as xenoestrogenic endocrine disrupting compounds (EDCs), include several kinds of: (1) estrogens, such as estrone (E1), 17 $\beta$-estradiol (E2), and $17 \alpha$-ethynylestradiol (EE2), (2) phenols, such as bisphenol A (BPA), and alkylphenols, such as 4octylphenol (4-OP) and 4-nonylphenol (4-NP), and
(3) phytoestrogens, such as daidzein (DAID), genistein (GEN) and biochanin A (BIO-A). These compounds have different origins and physical chemical properties but they all may cause, in polluted waters, endocrine disruption in fish (Jobling et al. 1998, 2002; Mills and Chichester 2005). Besides, there is evidence that mixtures of the above referred EDCs act as "estrogen cocktails" which are responsible for the appearance of several injuries in fish, including liver dysfunction and sexual disorders, such as the appearance of ovotestis (Vethaak et al. 2005). Thus, since urban, industrial and agricultural pollution still continue to exist in Mondego estuary and based on studies in a sentinel fish pointing to the presence of toxic compounds in this area (Santos et al. 2002), this study aimed to: (1) investigate the presence of EDCs such as natural and of synthetic estrogens, BPA, alkylphenols and phytoestrogens in the Mondego estuarine waters; (2) verify if any of the studied EDCs exists in hazardous amounts; (3) verify if there are seasonal fluctuations in the proposed EDCs concentrations; (4) study possible concentration gradients of the EDCs along the estuary and the effects of tides; and finally (5) identify eventual "hot spots" of pollution.

\section{Materials and methods}

Study area

The Mondego River estuary is located on the west coast of Portugal $\left(40^{\circ} 08^{\prime} \mathrm{N}, 8^{\circ} 50^{\prime} \mathrm{W}\right.$; Fig. 1). At about $5.5 \mathrm{~km}$ from the sea it branches into two arms (north and south), which then converge again near the mouth, the sampling point S1 (Fig. 1). The north arm (sampling point S2) is deeper (4-8 $\mathrm{m}$ during high tide, tidal range $1-3 \mathrm{~m}$ ), highly hydrodynamic and constitutes the main navigation channel and the location of the Figueira da Foz harbour. The south arm (sampling point S3) is shallower (2-4 m during high tide, tidal range $1-3 \mathrm{~m}$ ) and is characterized by large areas of exposed intertidal flats during low tide. The southern arm is almost silted up in the upper zones, so that the freshwater outflow is mainly via the northern arm. Circulation in the southern arm is mostly dependent on the tides and on the freshwater input from the Pranto River, a small tributary (sampling point S4). Sampling points S5 to S8 were equidistantly located from each other, about $3 \mathrm{~km}$, 
Fig. 1 Map of the Mondego River estuary showing the locations of the eight sampling areas (S1 to S8) selected for this study

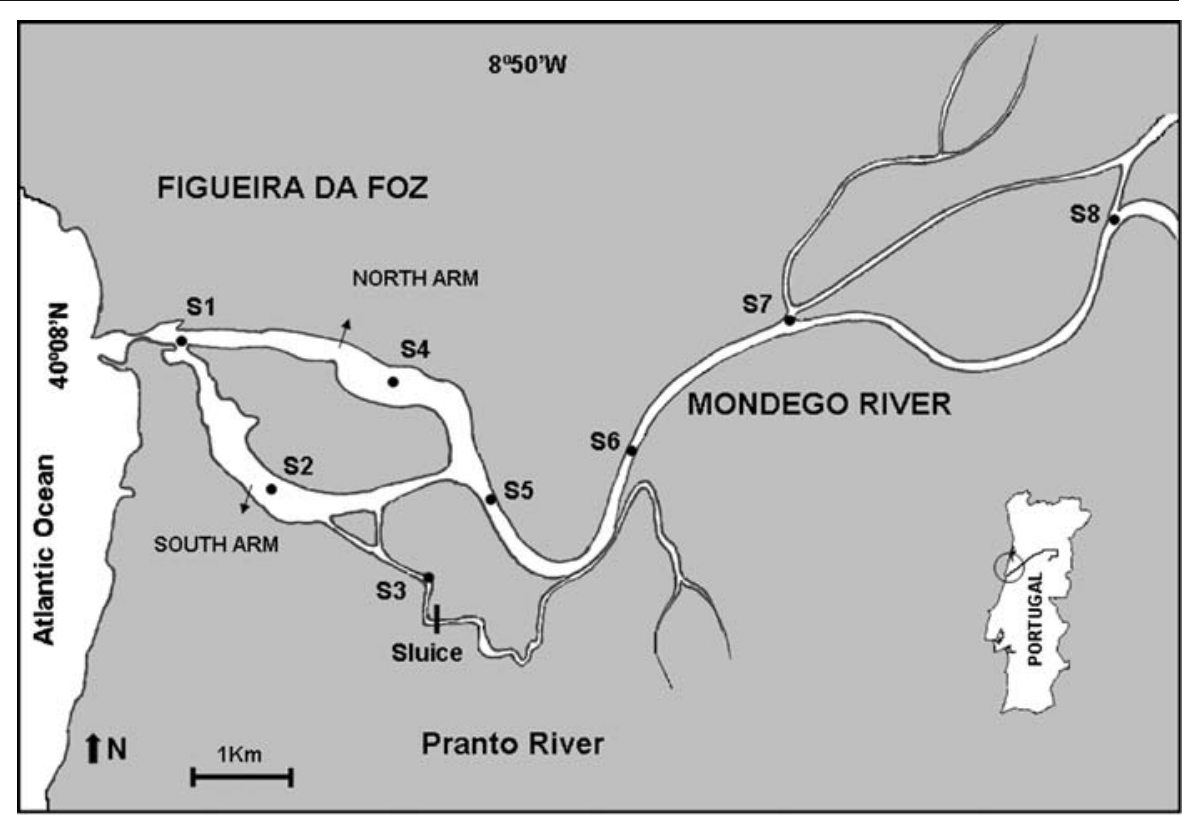

and all were located along the main branch of the estuary.

\section{Sampling collection}

Seasonally, during a yearly cycle representing the peak of winter (December 2005), spring (April 2006), summer (August 2006) and autumn (October 2006), estuarine water samples were collected systematically along the estuarine gradient (Fig. 1). For this study, 2 $\mathrm{L}$ of estuarine water samples were collected from a boat using a peristaltic pump considering, always, the high and low tides of Mondego River estuary. Additionally, in high tides sampling was done both in surface and in deep estuarine waters. The latter samples were collected at $8.5 \mathrm{~m}$ deep in the $\mathrm{S} 1$ sampling point, at $2.5 \mathrm{~m}$ deep in the north arm (S2), at $2.0 \mathrm{~m}$ deep in the south arm (S3), at $2.5 \mathrm{~m}$ deep in the Pranto River tributary (S4) and about $3.0 \mathrm{~m}$ deep in the estuary main branch (S5-S8). During sampling, all bottles were rinsed two or three times before the collection of the estuarine water samples. These, were immediately filtrated, to eliminate particulate matter and other suspended solid, through a $47 \mathrm{~mm} \mathrm{GF/C}$ glass fiber filter acquired from Millipore (Ireland). After this procedure, each filter was washed with small amounts of $\mathrm{CH}_{3} \mathrm{OH}$ that were added to the filtrate before the solid phase extraction (SPE) procedure. Finally, all samples were acidified with
$\mathrm{H}_{2} \mathrm{SO}_{4}$ to $\mathrm{pH} 2$ to prevent possible biodegradation. During transport to laboratory all flasks were stored at ca. $5^{\circ} \mathrm{C}$. In parallel, water samples from all the above referred points were collected in order to evaluate some physical-chemical parameters of the sampling areas (salinity, $\mathrm{pH}$, temperature, and dissolved oxygen).

\section{Chemicals}

Estrone (E1), 17ß-estradiol (E2), ethynylestradiol (EE2), bisphenol A (BPA), 4-octylphenol (4-OP), daidzein (DAID), genistein (GEN) and biochanin A (BIO-A) were obtained from Sigma-Aldrich (Steinhein, Germany) and 4-nonylphenol (4-NP) was obtained from Riedel-de-Haën (Seelze-Hannover, Germany; Fig. 2). Stock solutions of individual standards were prepared by dissolving known amounts of each compound in $\mathrm{CH}_{3} \mathrm{OH}: \mathrm{CH}_{3} \mathrm{CN}(50: 50, v / v)$ HPLC-grade, acquired from Sigma-Aldrich (Steinhein, Germany), to obtain final concentrations of $500 \mathrm{mg} / \mathrm{L}$. Other solvents were of analytical grade and were supplied by SigmaAldrich (Steinhein, Germany). Ultrapure water was supplied by a Milli-Q water system.

\section{Sample preparation}

Previously filtered and acidified, all estuarine water samples $(2 \mathrm{~L})$ were vacuum forced, at constant flow rate of $5-7 \mathrm{~mL} / \mathrm{min}$, through a $500 \mathrm{mg}$ Oasis HLB 
Fig. 2 Chemical structure of all EDCs investigated in Mondego River estuary

\section{Animal and pharmaceutical estrogens}<smiles>C[C@]12CCC3c4ccc(O)cc4CCC3C1CC[C@@H]2O</smiles>

17ß-Estradiol (E2)<smiles>C[C@]12CCC3c4ccc(O)cc4CCC3C1CCC2=O</smiles>

Estrone (E1)<smiles>C#C[C@]1(O)CCC2C3CCc4cc(O)ccc4C3CC[C@]21C</smiles>

17 $\alpha$-Ethynylestradiol (EE2)

\section{Phytoestrogens}<smiles>O=C1c2ccc(O)cc2OCC1c1ccc(O)cc1</smiles>

Daidzein (DAD)<smiles>O=C1c2c(O)cc(O)cc2OCC1c1ccc(O)cc1</smiles>

Genistein (GEN)<smiles>COc1ccc(C2COc3cc(O)cc(O)c3C2=O)cc1</smiles>

Biochanin A (BIO-A)

\section{Industrial pollut ants}<smiles>CC(C)(c1ccc(O)cc1)c1ccc(O)cc1</smiles>

Bisphenol A (BPA)

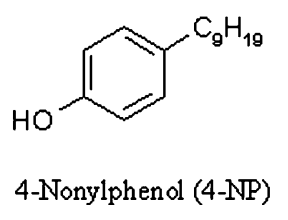<smiles>CCCc1ccc(O)cc1</smiles>

4-Octylphenol (4-OP)

Cartridge, purchased from Waters Corporation (Milford, MA, USA). Prior to use, this cartridge was sequentially washed with $25 \mathrm{~mL}$ of $\mathrm{CH}_{2} \mathrm{Cl}_{2}: \mathrm{CH}_{3} \mathrm{OH}(50: 50, v / v), 12$ $\mathrm{mL}$ of $\mathrm{CH}_{3} \mathrm{OH}$ and $25 \mathrm{~mL}$ of ultrapure Milli-Q water. After the addition of the water samples, the cartridges were washed with $25 \mathrm{~mL}$ of ultrapure Milli-Q water and $1 \mathrm{~mL}$ of $\mathrm{CH}_{3} \mathrm{OH}$ and all eluates were discarded. Afterwards, the cartridges were kept under vacuum aspiration, for $30 \mathrm{~min}$, to dry out residual water. The elution process, was performed with $20 \mathrm{~mL}$ of $\mathrm{CH}_{2} \mathrm{Cl}_{2}$ : $\mathrm{CH}_{3} \mathrm{OH}(50: 50, v / v)$, nonetheless, since the extracts from the estuarine water samples had a dark and sticky appearance, a cleanup step based in anterior protocols (Quintana et al. 2004; Beck et al. 2005), was implemented for the current assays (Ribeiro et al. 2007). Here, all extracts were quantitatively transferred to the $1 \mathrm{~g}$ Sep-Pak silica cartridges, acquired from Waters Corporation (Milford, MA, USA). Briefly, the SPE extracts were quantitatively transferred to the silica cartridges, previously washed with $\mathrm{CH}_{2} \mathrm{Cl}_{2}$. $\mathrm{CH}_{3} \mathrm{OH}(50: 50, v / v)$, and eluted with $7 \mathrm{~mL}$ of $\mathrm{CH}_{2} \mathrm{Cl}_{2}: \mathrm{CH}_{3} \mathrm{OH}(50: 50, v / v)$. Then, these eluates were collected in a round-bottomed tube and evaporated to dryness in a thermostatic bath at $40^{\circ} \mathrm{C}$ under a nitrogen stream and further dissolved in $200 \mu \mathrm{L}$ of $\mathrm{CH}_{3} \mathrm{OH}$ :

$\mathrm{CH}_{3} \mathrm{CN}(50: 50, v / v)$. Because this study used two different chromatographic methodologies, the HPLCDAD and the GC-MS, $20 \mu \mathrm{L}$ of each sample was injected in triplicate into the HPLC-DAD system for quantitative analysis and $50 \mu \mathrm{L}$ was derivatized with MSTFA before injection in the GC-MS equipment. In this system the identity of all quantified compounds were confirmed and, furthermore, it was investigated the presence of other chemicals that, due to their low environmental concentrations, were under the detection limits of the applied HPLC-DAD method. The recovery rates for the majority of the EDCs were higher than $94 \%$, with the exception of BIO-A (91\%), 4-OP (70\%) and 4-NP (61\%) that show, on average, lower recovery rates (Ribeiro et al. 2007).

Chromatographic system and main methodological characteristics

The liquid chromatographic system consisted of a LiChroCART $\mathrm{C}_{18}$ reversed-phase analytical column $250 \times 4 \mathrm{~mm}$ i.d., $5 \mu \mathrm{m}$ particle sizes (Merck, Darmstadt, Germany) and a Merck Hitachi HPLC apparatus, equipped with the LaChrom diode array detector L7455. Data acquisition was performed by a HPLC 
System Manager HSM D-7000, Version 3.0 (MerckHitachi). The chromatographic analysis was performed at room temperature using a gradient solvent program with a flow rate of $1 \mathrm{~mL} / \mathrm{min}$. The initial composition of the mobile phase was $\mathrm{CH}_{3} \mathrm{CN}: \mathrm{H}_{2} \mathrm{O}(25: 75, v / v)$ acidified with $\mathrm{CF}_{3} \mathrm{CO}_{2} \mathrm{H}, \mathrm{pH} 2$, in order to suppress the ionic moieties of all assayed compounds. The gradient was programmed to increase the amount of organic solvent as follows: $0-5$ (25-40\%), 5-14 (40-55\%), 14-17 (55-57\%) and 17-30 min (57-90\%). After the chromatographic run, the amount of $\mathrm{CH}_{3} \mathrm{CN}$ was increased to $100 \%$ and maintained isocratically during $5 \mathrm{~min}$ before a new injection. The wavelengths used for detection of the nine EDCs proposed in this study were $246 \mathrm{~nm}$ for DAID, $260 \mathrm{~nm}$ for GEN and BIO-A, $278 \mathrm{~nm}$ for BPA, 4-OP and 4-NP, and, $280 \mathrm{~nm}$ for E1, E2 and EE2. All working calibration curves used for the calculation of the levels of the latest EDCs showed correlation factors higher than 0.99 , and peak areas were used for the present quantitative analysis (Ribeiro et al. 2007). During the application of the last validated method several quality control parameters accordingly to the International Conference of Harmonization ( $\mathrm{ICH}$ 1996) guidelines. Namely, those concerning the robustness of the method, i.e., the instrumental precision accuracy was determined during each analytical assay by the measurement of the peak areas of injections containing both standard mixture and fortified matrix $(\mathrm{RSD}<1 \%)$. Furthermore, the maintenance of the retention times among samples and standards was always verified as, each analysed sample was injected both individually $(n=2)$ and spiked with all standards $(n=1)$. Finally only the areas of peaks showing a purity higher than $99 \%$ (this value was calculated automatically by the HPLC-DAD software) were considered for the quantitative analysis, which, was based in a calibration curve built for this propose (Ribeiro et al. 2007).

Later on, the identities of all compounds measured in this study by HPLC-DAD were re-confirmed, in the same estuarine water samples, by GC-MS analysis. The gas chromatographic system consisted in a Varian CP 3800 apparatus equipped with a VF-5ms type capillary column $(30 \mathrm{~m} \times 0.25 \mathrm{~mm}$ i.d., $d f: 0.25$ $\mu \mathrm{m})$ connected to an ion trap mass spectrometer (Varian Saturn 2200). The GC-MS analytical procedure used for the current estuarine water samples was based in several published protocols (Lee et al. 2004; Ballesteros et al. 2006; Shareef et al. 2006) and was adjusted to the current samples accordingly to Silveira (2007). Thus, as the majority of the EDCs analysed (Fig. 2) contain hydroxyl groups in a steric hindrance position, the MSTFA was the ideal silylation reagent to simultaneous derivatization of all hydroxyl group to prepare the trimethylsilyl (TMS) derivatives (Lee et al. 2004; Shareef et al. 2006). Data acquisition was obtained using the selected ion monitoring (SIM) mode. The identification of each chromatographic peak was achieved by comparing the retention times of the standards with those obtained for samples and matching the characteristic ions of each EDC in samples, standards and mixtures of standards with samples.

\section{Results and discussions}

Data are displayed in Table 1, and in Figs. 3, 4 and 5. Before analysing the EDCs concentration data in Table 1 it is important to stress that, following a continuous trend, 2005 was the hottest and the driest year of the last six decades in Portugal. This fact, allied to the large areas affected by forest burning and the high water temperatures registered in the Mondego River estuary in December of 2005 (Fig. 3), hypothetically affected the normal conditions of this region. Therefore, and comparatively to the results obtained in October of 2006 (autumn), in December 2005 (winter) it was possible to measure high levels of phytoestrogens (DAID and BIO-A) at all sampling points of the estuary (Table 1). Since at least the physical conditions for the emergence of eutrophication occurred in December of 2005 (Bacelar-Nicolau et al. 2003; Lillebo et al. 2005) and because the sampling point that registered the highest temperature $\left(13.5^{\circ} \mathrm{C}\right)$ and dissolved oxygen $(10.1 \mathrm{mg} / \mathrm{L})$ is the same (S3 sampling area) where the highest levels of both DAID and BIO-A were registered, the above hypothesis seems quite probable. In fact, in December of 2005 the total load of DAID and BIO-A at the S3 sampling point was, in high tide, $57.6 \mathrm{ng} / \mathrm{L}$ (surface) and $155.0 \mathrm{ng} / \mathrm{L}$ (deep; Table 1 and Fig. 4a). The identity of these compounds in all samples were evaluated by the DAD detector and later confirmed by the MS detector associated to the GC apparatus. In Fig. 5, it is shown the fragmentation peaks characteristic of DAID (383 and $398 \mathrm{~m} / \mathrm{z}$ ), GEN (399 and 471 
Table 1 Concentrations of all EDCs measured in each of the sampling sites (S1 to S8) of the Mondego River estuary

\begin{tabular}{|c|c|c|c|c|c|c|c|c|c|c|c|c|c|}
\hline \multirow{3}{*}{$\begin{array}{l}\text { Quantified } \\
\text { EDCs } \\
(\mathrm{ng} / \mathrm{L})\end{array}$} & \multirow{3}{*}{$\begin{array}{l}\text { Sampling } \\
\text { points }\end{array}$} & \multicolumn{3}{|c|}{ December 2005} & \multicolumn{3}{|c|}{ April 2006} & \multicolumn{3}{|c|}{ August 2006} & \multicolumn{3}{|c|}{ October 2006} \\
\hline & & \multicolumn{2}{|c|}{ High tide } & \multirow{2}{*}{$\frac{\text { Low tide }}{\text { Surface }}$} & \multicolumn{2}{|c|}{ High tide } & \multirow{2}{*}{$\frac{\text { Low tide }}{\text { Surface }}$} & \multicolumn{2}{|c|}{ High tide } & \multirow{2}{*}{$\frac{\text { Low tide }}{\text { Surface }}$} & \multicolumn{2}{|c|}{ High tide } & \multirow{2}{*}{$\frac{\text { Low tide }}{\text { Surface }}$} \\
\hline & & Surface & Deep & & Surface & Deep & & Surface & Deep & & Surface & Deep & \\
\hline \multirow[t]{8}{*}{ DAID } & $\mathrm{S} 1$ & 41.3 & 72.1 & $<3.0^{\mathrm{a}}$ & $<3.0^{\mathrm{a}}$ & $<3.0^{\mathrm{a}}$ & $<3.0^{\mathrm{a}}$ & $<3.0^{\mathrm{a}}$ & $<3.0^{\mathrm{a}}$ & $<3.0^{\mathrm{a}}$ & $<3.0^{\mathrm{a}}$ & $<3.0^{\mathrm{a}}$ & $<3.0^{\mathrm{a}}$ \\
\hline & $\mathrm{S} 2$ & 34.3 & 25.5 & 129.2 & $<3.0^{\mathrm{a}}$ & 77.5 & 224.3 & $<3.0^{\mathrm{a}}$ & $<3.0^{\mathrm{a}}$ & $<3.0^{\mathrm{a}}$ & $<3.0^{\mathrm{a}}$ & $<3.0^{\mathrm{a}}$ & $<3.0^{\mathrm{a}}$ \\
\hline & $\mathrm{S} 3$ & 44.7 & 126.6 & $<3.0^{\mathrm{a}}$ & 164.0 & 31.7 & 11.1 & $<3.0^{\mathrm{a}}$ & $<3.0^{\mathrm{a}}$ & $<3.0^{\mathrm{a}}$ & $<3.0^{\mathrm{a}}$ & $<3.0^{\mathrm{a}}$ & $<3.0^{\mathrm{a}}$ \\
\hline & $\mathrm{S} 4$ & 16.0 & 69.3 & $<3.0^{\mathrm{a}}$ & $<3.0^{\mathrm{a}}$ & $<3.0^{\mathrm{a}}$ & 401.7 & $<3.0^{\mathrm{a}}$ & $<3.0^{\mathrm{a}}$ & $<3.0^{\mathrm{a}}$ & $<3.0^{\mathrm{a}}$ & $<3.0^{\mathrm{a}}$ & $<3.0^{\mathrm{a}}$ \\
\hline & S5 & 82.8 & 106.6 & 34.9 & 11.7 & 174.0 & $<3.0^{\mathrm{a}}$ & $<3.0^{\mathrm{a}}$ & $<3.0^{\mathrm{a}}$ & $<3.0^{\mathrm{a}}$ & $<3.0^{\mathrm{a}}$ & $<3.0^{\mathrm{a}}$ & $<3.0^{\mathrm{a}}$ \\
\hline & S6 & 31.8 & 32.0 & 25.7 & $<3.0^{\mathrm{a}}$ & $<3.0^{\mathrm{a}}$ & $<3.0^{\mathrm{a}}$ & $<3.0^{\mathrm{a}}$ & $<3.0^{\mathrm{a}}$ & $<3.0^{\mathrm{a}}$ & $<3.0^{\mathrm{a}}$ & $<3.0^{\mathrm{a}}$ & $<3.0^{\mathrm{a}}$ \\
\hline & S7 & 93.3 & 22.8 & 6.2 & $<3.0^{\mathrm{a}}$ & $<3.0^{\mathrm{a}}$ & 191.0 & $<3.0^{\mathrm{a}}$ & $<3.0^{\mathrm{a}}$ & $<3.0^{\mathrm{a}}$ & $<3.0^{\mathrm{a}}$ & $<3.0^{\mathrm{a}}$ & $<3.0^{\mathrm{a}}$ \\
\hline & S8 & 24.0 & 28.9 & 21.7 & $<3.0^{\mathrm{a}}$ & 198.0 & 526.0 & $<3.0^{\mathrm{a}}$ & $<3.0^{\mathrm{a}}$ & $<3.0^{\mathrm{a}}$ & $<3.0^{\mathrm{a}}$ & $<3.0^{\mathrm{a}}$ & $<3.0^{\mathrm{a}}$ \\
\hline \multirow[t]{8}{*}{ BIO-A } & $\mathrm{S} 1$ & 11.0 & 11.8 & $<8.4^{\mathrm{a}}$ & $<8.4^{\mathrm{a}}$ & $<8.4^{\mathrm{a}}$ & $<8.4^{\mathrm{a}}$ & $<8.4^{\mathrm{a}}$ & $<8.4^{\mathrm{a}}$ & $<8.4^{\mathrm{a}}$ & $<8.4^{\mathrm{a}}$ & $<8.4^{\mathrm{a}}$ & $<8.4^{\mathrm{a}}$ \\
\hline & $\mathrm{S} 2$ & 12.5 & 21.0 & 15.4 & 46.1 & $<8.4^{\mathrm{a}}$ & $<8.4^{\mathrm{a}}$ & $<8.4^{\mathrm{a}}$ & $<8.4^{\mathrm{a}}$ & $<8.4^{\mathrm{a}}$ & $<8.4^{\mathrm{a}}$ & $<8.4^{\mathrm{a}}$ & $<8.4^{\mathrm{a}}$ \\
\hline & $\mathrm{S} 3$ & 12.9 & 28.4 & $<8.4^{\mathrm{a}}$ & $<8.4^{\mathrm{a}}$ & $<8.4^{\mathrm{a}}$ & $<8.4^{\mathrm{a}}$ & $<8.4^{\mathrm{a}}$ & $<8.4^{\mathrm{a}}$ & $<8.4^{\mathrm{a}}$ & $<8.4^{\mathrm{a}}$ & $<8.4^{\mathrm{a}}$ & $<8.4^{\mathrm{a}}$ \\
\hline & $\mathrm{S} 4$ & $<8.4^{\mathrm{a}}$ & 10.9 & 19.5 & $<8.4^{\mathrm{a}}$ & $<8.4^{\mathrm{a}}$ & 60.2 & $<8.4^{\mathrm{a}}$ & $<8.4^{\mathrm{a}}$ & $<8.4^{\mathrm{a}}$ & $<8.4^{\mathrm{a}}$ & $<8.4^{\mathrm{a}}$ & $<8.4^{\mathrm{a}}$ \\
\hline & S5 & 14.7 & 25.4 & 29.3 & $<8.4^{\mathrm{a}}$ & $<8.4^{\mathrm{a}}$ & $<8.4^{\mathrm{a}}$ & $<8.4^{\mathrm{a}}$ & $<8.4^{\mathrm{a}}$ & $<8.4^{\mathrm{a}}$ & $<8.4^{\mathrm{a}}$ & $<8.4^{\mathrm{a}}$ & $<8.4^{\mathrm{a}}$ \\
\hline & S6 & $<8.4^{\mathrm{a}}$ & $<8.4^{\mathrm{a}}$ & $<8.4^{\mathrm{a}}$ & $<8.4^{\mathrm{a}}$ & $<8.4^{\mathrm{a}}$ & $<8.4^{\mathrm{a}}$ & $<8.4^{\mathrm{a}}$ & $<8.4^{\mathrm{a}}$ & $<8.4^{\mathrm{a}}$ & $<8.4^{\mathrm{a}}$ & $<8.4^{\mathrm{a}}$ & 36.0 \\
\hline & S7 & $<8.4^{\mathrm{a}}$ & $<8.4^{\mathrm{a}}$ & $<8.4^{\mathrm{a}}$ & $<8.4^{\mathrm{a}}$ & $<8.4^{\mathrm{a}}$ & $<8.4^{\mathrm{a}}$ & $<8.4^{\mathrm{a}}$ & $<8.4^{\mathrm{a}}$ & $<8.4^{\mathrm{a}}$ & $<8.4^{\mathrm{a}}$ & $<8.4^{\mathrm{a}}$ & 23.3 \\
\hline & S8 & 12.1 & 23.0 & 12.8 & $<8.4^{\mathrm{a}}$ & $<8.4^{\mathrm{a}}$ & 30.9 & $<8.4^{\mathrm{a}}$ & $<8.4^{\mathrm{a}}$ & $<8.4^{\mathrm{a}}$ & $<8.4^{\mathrm{a}}$ & 15.6 & 24.1 \\
\hline \multirow[t]{8}{*}{ GEN } & $\mathrm{S} 1$ & $<2.6^{\mathrm{a}}$ & $<2.6^{\mathrm{a}}$ & $<2.6^{\mathrm{a}}$ & $<2.6^{\mathrm{a}}$ & 22.5 & $<2.6^{\mathrm{a}}$ & $<2.6^{\mathrm{a}}$ & $<2.6^{\mathrm{a}}$ & $<2.6^{\mathrm{a}}$ & $<2.6^{\mathrm{a}}$ & $<2.6^{\mathrm{a}}$ & $<2.6^{\mathrm{a}}$ \\
\hline & $\mathrm{S} 2$ & $<2.6^{\mathrm{a}}$ & $<2.6^{\mathrm{a}}$ & $<2.6^{\mathrm{a}}$ & $<2.6^{\mathrm{a}}$ & $<2.6^{\mathrm{a}}$ & $<2.6^{\mathrm{a}}$ & $<2.6^{\mathrm{a}}$ & $<2.6^{\mathrm{a}}$ & $<2.6^{\mathrm{a}}$ & $<2.6^{\mathrm{a}}$ & $<2.6^{\mathrm{a}}$ & $<2.6^{\mathrm{a}}$ \\
\hline & $\mathrm{S} 3$ & $<2.6^{\mathrm{a}}$ & $<2.6^{\mathrm{a}}$ & $<2.6^{\mathrm{a}}$ & $<2.6^{\mathrm{a}}$ & $<2.6^{\mathrm{a}}$ & $<2.6^{\mathrm{a}}$ & $<2.6^{\mathrm{a}}$ & $<2.6^{\mathrm{a}}$ & $<2.6^{\mathrm{a}}$ & $<2.6^{\mathrm{a}}$ & $<2.6^{\mathrm{a}}$ & $<2.6^{\mathrm{a}}$ \\
\hline & $\mathrm{S} 4$ & $<2.6^{\mathrm{a}}$ & $<2.6^{\mathrm{a}}$ & $<2.6^{\mathrm{a}}$ & $<2.6^{\mathrm{a}}$ & $<2.6^{\mathrm{a}}$ & 32.6 & $<2.6^{\mathrm{a}}$ & $<2.6^{\mathrm{a}}$ & $<2.6^{\mathrm{a}}$ & $<2.6^{\mathrm{a}}$ & $<2.6^{\mathrm{a}}$ & $<2.6^{\mathrm{a}}$ \\
\hline & S5 & $<2.6^{\mathrm{a}}$ & $<2.6^{\mathrm{a}}$ & $<2.6^{\mathrm{a}}$ & $<2.6^{\mathrm{a}}$ & $<2.6^{\mathrm{a}}$ & $<2.6^{\mathrm{a}}$ & $<2.6^{\mathrm{a}}$ & $<2.6^{\mathrm{a}}$ & $<2.6^{\mathrm{a}}$ & $<2.6^{\mathrm{a}}$ & $<2.6^{\mathrm{a}}$ & $<2.6^{\mathrm{a}}$ \\
\hline & S6 & $<2.6^{\mathrm{a}}$ & $<2.6^{\mathrm{a}}$ & $<2.6^{\mathrm{a}}$ & $<2.6^{\mathrm{a}}$ & $<2.6^{\mathrm{a}}$ & $<2.6^{\mathrm{a}}$ & $<2.6^{\mathrm{a}}$ & $<2.6^{\mathrm{a}}$ & $<2.6^{\mathrm{a}}$ & $<2.6^{\mathrm{a}}$ & $<2.6^{\mathrm{a}}$ & $<2.6^{\mathrm{a}}$ \\
\hline & S7 & $<2.6^{\mathrm{a}}$ & $<2.6^{\mathrm{a}}$ & $<2.6^{\mathrm{a}}$ & $<2.6^{\mathrm{a}}$ & $<2.6^{\mathrm{a}}$ & $<2.6^{\mathrm{a}}$ & $<2.6^{\mathrm{a}}$ & $<2.6^{\mathrm{a}}$ & $<2.6^{\mathrm{a}}$ & $<2.6^{\mathrm{a}}$ & $<2.6^{\mathrm{a}}$ & $<2.6^{\mathrm{a}}$ \\
\hline & S8 & $<2.6^{\mathrm{a}}$ & $<2.6^{\mathrm{a}}$ & $<2.6^{\mathrm{a}}$ & $<2.6^{\mathrm{a}}$ & $<2.6^{\mathrm{a}}$ & 507.1 & $<2.6^{\mathrm{a}}$ & $<2.6^{\mathrm{a}}$ & $<2.6^{\mathrm{a}}$ & $<2.6^{\mathrm{a}}$ & $<2.6^{\mathrm{a}}$ & $<2.6^{\mathrm{a}}$ \\
\hline \multirow[t]{8}{*}{ BPA } & $\mathrm{S} 1$ & $<6.6^{\mathrm{a}}$ & $<6.6^{\mathrm{a}}$ & $<6.6^{\mathrm{a}}$ & $<6.6^{\mathrm{a}}$ & $<6.6^{\mathrm{a}}$ & $<6.6^{\mathrm{a}}$ & $<6.6^{\mathrm{a}}$ & $<6.6^{\mathrm{a}}$ & $<6.6^{\mathrm{a}}$ & $<6.6^{\mathrm{a}}$ & $<6.6^{\mathrm{a}}$ & 670.2 \\
\hline & $\mathrm{S} 2$ & $<6.6^{\mathrm{a}}$ & $<6.6^{\mathrm{a}}$ & $<6.6^{\mathrm{a}}$ & $<6.6^{\mathrm{a}}$ & $<6.6^{\mathrm{a}}$ & $<6.6^{\mathrm{a}}$ & $<6.6^{\mathrm{a}}$ & $<6.6^{\mathrm{a}}$ & $<6.6^{\mathrm{a}}$ & $<6.6^{\mathrm{a}}$ & $<6.6^{\mathrm{a}}$ & 880.0 \\
\hline & $\mathrm{S} 3$ & $<6.6^{\mathrm{a}}$ & $<6.6^{\mathrm{a}}$ & $<6.6^{\mathrm{a}}$ & $<6.6^{\mathrm{a}}$ & $<6.6^{\mathrm{a}}$ & $<6.6^{\mathrm{a}}$ & $<6.6^{\mathrm{a}}$ & $<6.6^{\mathrm{a}}$ & $<6.6^{\mathrm{a}}$ & $<6.6^{\mathrm{a}}$ & $<6.6^{\mathrm{a}}$ & $<6.6^{\mathrm{a}}$ \\
\hline & $\mathrm{S} 4$ & $<6.6^{\mathrm{a}}$ & $<6.6^{\mathrm{a}}$ & $<6.6^{\mathrm{a}}$ & $<6.6^{\mathrm{a}}$ & $<6.6^{\mathrm{a}}$ & $<6.6^{\mathrm{a}}$ & $<6.6^{\mathrm{a}}$ & $<6.6^{\mathrm{a}}$ & $<6.6^{\mathrm{a}}$ & $<6.6^{\mathrm{a}}$ & $<6.6^{\mathrm{a}}$ & $<6.6^{\mathrm{a}}$ \\
\hline & S5 & $<6.6^{\mathrm{a}}$ & $<6.6^{\mathrm{a}}$ & $<6.6^{\mathrm{a}}$ & $<6.6^{\mathrm{a}}$ & $<6.6^{\mathrm{a}}$ & $<6.6^{\mathrm{a}}$ & $<6.6^{\mathrm{a}}$ & $<6.6^{\mathrm{a}}$ & $<6.6^{\mathrm{a}}$ & 326.7 & $<6.6^{\mathrm{a}}$ & 325.8 \\
\hline & S6 & $<6.6^{\mathrm{a}}$ & $<6.6^{\mathrm{a}}$ & $<6.6^{\mathrm{a}}$ & $<6.6^{\mathrm{a}}$ & $<6.6^{\mathrm{a}}$ & $<6.6^{\mathrm{a}}$ & $<6.6^{\mathrm{a}}$ & $<6.6^{\mathrm{a}}$ & $<6.6^{\mathrm{a}}$ & 178.0 & $<6.6^{\mathrm{a}}$ & 276.6 \\
\hline & S7 & $<6.6^{\mathrm{a}}$ & $<6.6^{\mathrm{a}}$ & $<6.6^{\mathrm{a}}$ & $<6.6^{\mathrm{a}}$ & $<6.6^{\mathrm{a}}$ & $<6.6^{\mathrm{a}}$ & $<6.6^{\mathrm{a}}$ & $<6.6^{\mathrm{a}}$ & $<6.6^{\mathrm{a}}$ & 451.9 & 106.4 & 183.0 \\
\hline & S8 & $<6.6^{\mathrm{a}}$ & $<6.6^{\mathrm{a}}$ & $<6.6^{\mathrm{a}}$ & $<6.6^{\mathrm{a}}$ & $<6.6^{\mathrm{a}}$ & $<6.6^{\mathrm{a}}$ & $<6.6^{\mathrm{a}}$ & $<6.6^{\mathrm{a}}$ & $<6.6^{\mathrm{a}}$ & $<6.6^{\mathrm{a}}$ & $<6.6^{\mathrm{a}}$ & 589.5 \\
\hline E2 & $\mathrm{S} 1-\mathrm{S} 8$ & $<3.0^{\mathrm{a}}$ & $<3.0^{\mathrm{a}}$ & $<3.0^{\mathrm{a}}$ & $<3.0^{\mathrm{a}}$ & $<3.0^{\mathrm{a}}$ & $<3.0^{\mathrm{a}}$ & $<3.0^{\mathrm{a}}$ & $<3.0^{\mathrm{a}}$ & $<3.0^{\mathrm{a}}$ & $<3.0^{\mathrm{a}}$ & $<3.0^{\mathrm{a}}$ & $<3.0^{\mathrm{a}}$ \\
\hline EE2 & $\mathrm{S} 1-\mathrm{S} 8$ & $<12.0^{\mathrm{a}}$ & $<12.0^{\mathrm{a}}$ & $<12.0^{\mathrm{a}}$ & $<12.0^{\mathrm{a}}$ & $<12.0^{\mathrm{a}}$ & $<12.0^{\mathrm{a}}$ & $<12.0^{\mathrm{a}}$ & $<12.0^{\mathrm{a}}$ & $<12.0^{\mathrm{a}}$ & $<12.0^{\mathrm{a}}$ & $<12.0^{\mathrm{a}}$ & $<12.0^{\mathrm{a}}$ \\
\hline E1 & $\mathrm{S} 1-\mathrm{S} 8$ & $<5.0^{\mathrm{a}}$ & $<5.0^{\mathrm{a}}$ & $<5.0^{\mathrm{a}}$ & $<5.0^{\mathrm{a}}$ & $<5.0^{\mathrm{a}}$ & $<5.0^{\mathrm{a}}$ & $<5.0^{\mathrm{a}}$ & $<5.0^{\mathrm{a}}$ & $<5.0^{\mathrm{a}}$ & $<5.0^{\mathrm{a}}$ & $<5.0^{\mathrm{a}}$ & $<5.0^{\mathrm{a}}$ \\
\hline 4-OP & $\mathrm{S} 1-\mathrm{S} 8$ & $<2.0^{\mathrm{a}}$ & $<2.0^{\mathrm{a}}$ & $<2.0^{\mathrm{a}}$ & $<2.0^{\mathrm{a}}$ & $<2.0^{\mathrm{a}}$ & $<2.0^{\mathrm{a}}$ & $<2.0^{\mathrm{a}}$ & $<2.0^{\mathrm{a}}$ & $<2.0^{\mathrm{a}}$ & $<2.0^{\mathrm{a}}$ & $<2.0^{\mathrm{a}}$ & $<2.0$ \\
\hline
\end{tabular}

a $<$ Detection limit

$\mathrm{m} / \mathrm{z}$ ), and BIO-A (413 and $428 \mathrm{~m} / \mathrm{z}$ ) (Lee et al. 2004; Silveira 2007).

In April of 2006 (spring), the water temperatures continued to be very high comparatively to other years (Bacelar-Nicolau et al. 2003; Baeta et al. 2005), e.g., at the sampling station $\mathrm{S} 4$ the water temperature raised up to $21.4^{\circ} \mathrm{C}$. This fact, taken together with a decrease of dissolved oxygen in this area $(8.4 \mathrm{mg} / \mathrm{L}$ in December and $6.3 \mathrm{mg} / \mathrm{L}$ in April), suggested that there was a disruption of the local oxygen production vs. consumption (Fig. 3). Besides, in spring, there was the usual development of the corn and the rice plantations located all around this estuary, that surely contributed to the increase of the concentration of all 

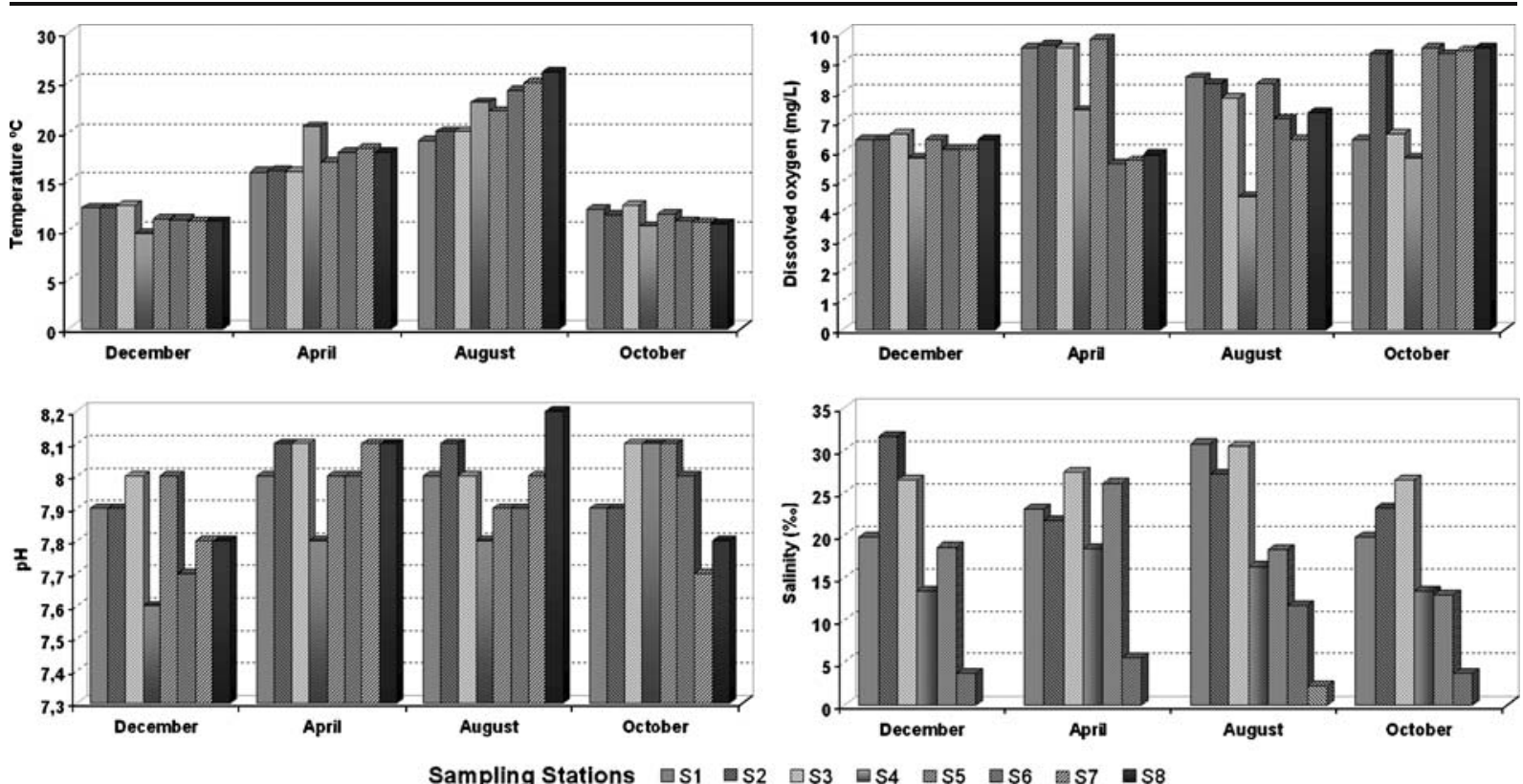

Fig. 3 Ranges of the physico-chemical parameters measured in each of the sampling sites (S1 to S8) of the Mondego River estuary

studied phytoestrogens, mainly GEN, an important component of cereals (Liggins et al. 2002) that was not detected in December. As to such data, it is interesting to observe that the measurement of the highest concentrations of all the phytoestrogens occurred at the sampling points S4 (up to $494.5 \mathrm{ng} / \mathrm{L}$ ) and S8 (up to $1.1 \mu \mathrm{g} / \mathrm{L}$ ) (Table 1 and Fig. 4b). These data may be a consequence of the leaching effects promoted by the agriculture activities, as the S4 sampling area receives the direct contribution of the Pranto River, which is a small tributary used for the irrigation of the rice fields in the Mondego Valley, and the S8 sampling area is located between large cultivated fields. Because studies in Japanese medaka, Oryzias latipes, revealed that fish exposed to $0.8 \mu \mathrm{g} / \mathrm{L}$ of equol (a metabolite of formonetin and DAID) and $1,000 \mu \mathrm{g} / \mathrm{L}$ of GEN showed an incidence of gonadal intersex of $87 \%$ and $12 \%$, respectively (Kiparissis et al. 2003) and, as the detected phytoestrogens - which identity was confirmed by MS (Fig. 5) - concur with other potentially dangerous compounds in this estuary (Diez et al. 2005; Pereira et al. 2005), we think that, at least in the S8 sampling area, they may contribute (as estrogen mimics) to sexual endocrine disruption in local fish. To address such hypothesis, studies are being conducted in feral animals living in this area.
Recent studies revealed the occurrence of chemical biodegradation conditions for temperatures and $\mathrm{pH}$ levels similar to those reported herein for August 2006 (Ahel et al. 1994; Chang et al. 2005), and so, because in this month the levels of all compounds found were below the detection limits of both analytical methods (HPLC-DAD and GC-MS), it is hypothesized that biodegradation occurred.

In October 2006 (autumn), BIO-A was the only detected phytoestrogen (up to $36.0 \mathrm{ng} / \mathrm{L}$ ). The absence of detectable levels of both DAID and GEN, present in corn and rice (Liggins et al. 2002), agreed with the common knowledge that in this season both corn and rice plantations were already cropped and with the seasonal variation of the indigenous flora of this estuary, which contains considerable amounts red clover (Trifolium ptatense L., Fabaceae) and many species of grasses that are rich sources of this phytoestrogen at this time of the year (Booth et al. 2006).

In contrast with other seasons, in autumn BPA was measured and identified in high amounts (up to 880.0 $\mathrm{ng} / \mathrm{L}$ ) in this estuary (Table 1 and Figs. $4 \mathrm{c}$ and $5 \mathrm{~d}$ ); the MS fragmentation peaks characteristic of the BPA ( 357 and $372 \mathrm{~m} / \mathrm{z}$ ) were identical to those reported by other authors using similar experimental conditions 

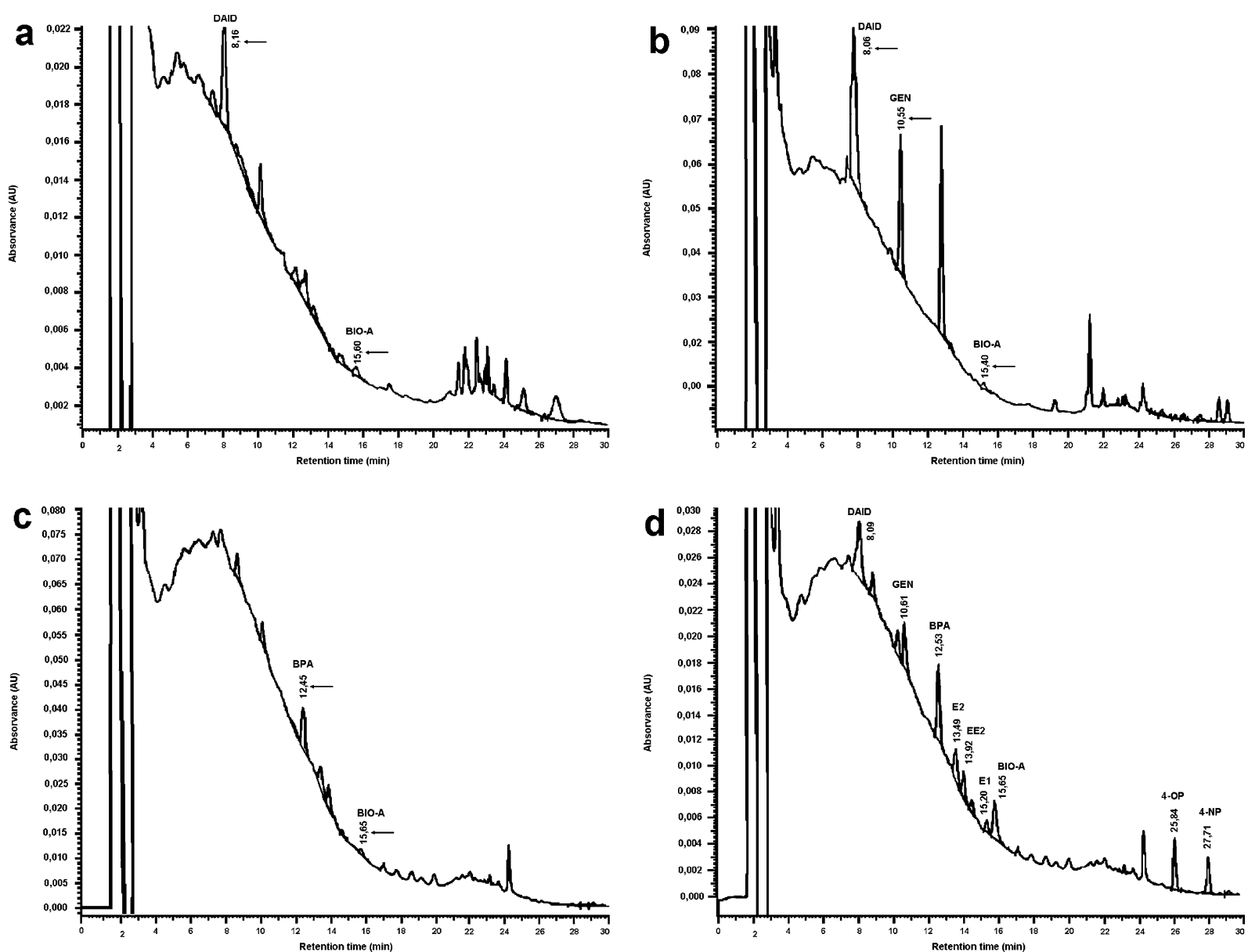

Fig. 4 Chromatograms of several samples a S3, high tide (deep), December 2005; b S8, low tide, April 2006; c S8, low tide, October 2006 and d S8, low tide, October 2006 spiked

(Ballesteros et al. 2006; Silveira 2007). The analysis of the current data suggested that this pollutant was dumped in this estuary at or before the S8 sampling point by an occasional and/or deliberate discharge of a yet unknown industrial origin. This assumption was made taking in account that this pollutant was never found in all other sampling surveys and, in spite of its rapid degradation levels (Kang and Kondo 2005) there was no accumulation of it in deep waters. Because BPA was identified as a weakly estrogenic substance, with effects on the breeding of some fish species, in concentrations at or higher than $640 \mu \mathrm{g} / \mathrm{L}$ (Sohoni et al. 2001; Staples et al. 2002) and because the levels measured for BPA in the surface waters of the Mondego estuary (Table 1) were considerably

lower than those reported before, it is possible that if endocrine disruption exists in this estuary it is not promoted by the individual contribution of this compound but by the synergetic effect of all chemicals as a whole.

Finally, it is important to stress that in all samples the levels of all assayed estrogens and alkylphenols were under the detection limits of both HPLC-DAD and GC-MS analytical methods. Considering that the population in the watershed of the Mondego River estuary is about 65,700 inhabitants and that the upper section of the Mondego River has low to moderate human impacts these may possible explain why estrogens and alkylphenols were under the detection limits of both HPLC-DAD and GC-MS methods. 

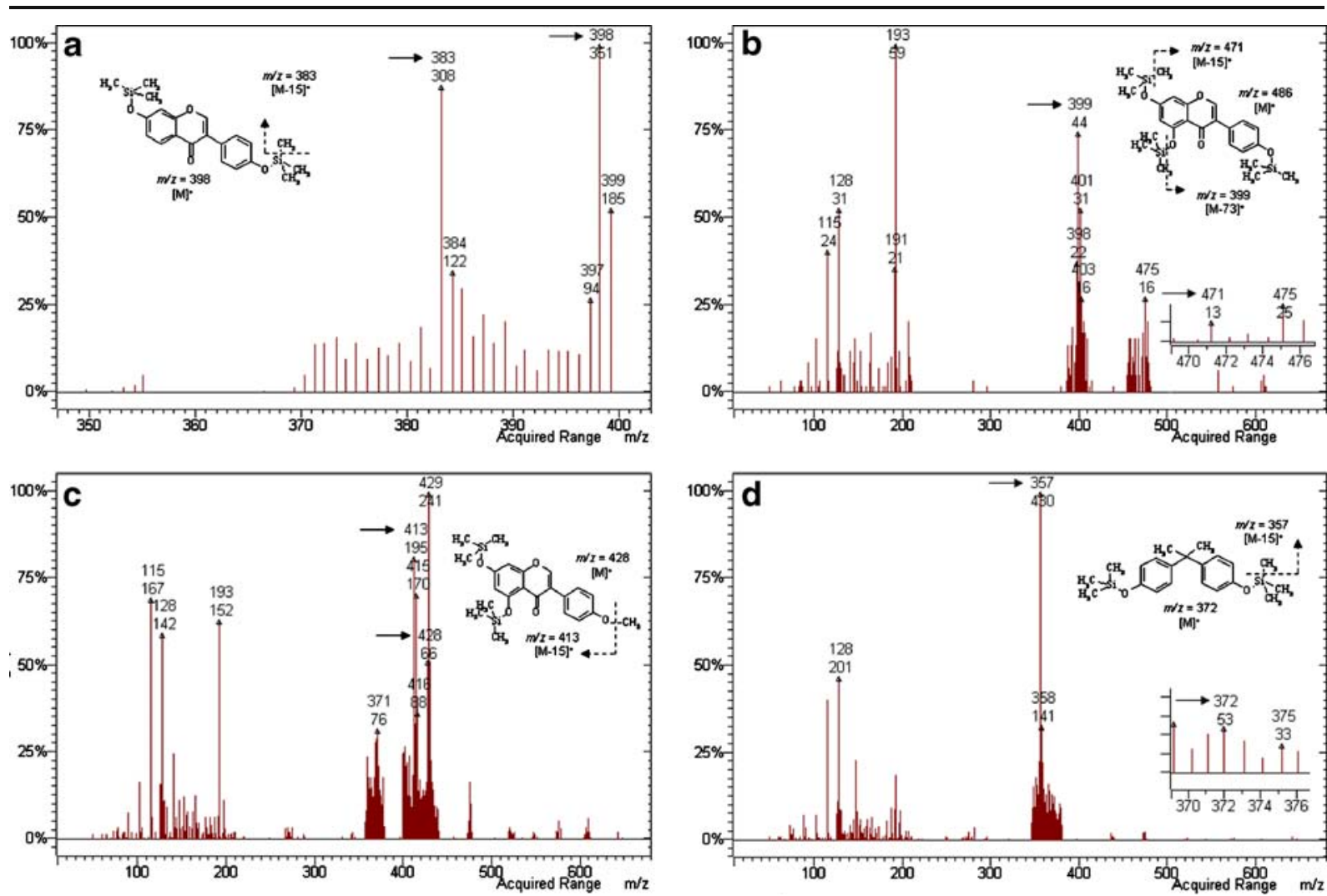

Fig. 5 MS spectra of all detected compounds in the Mondego River estuary. The arrows point to the peaks $(\mathrm{m} / \mathrm{z})$ used for the identification of DAID (a), GEN (b), BIO-A (c), and BPA (d)

\section{Conclusions}

(1) The present study identified the presence of phytoestrogens (DAID, BIO-A and GEN) and BPA in the Mondego River estuary, furthermore demonstrating the absence of measurable levels of estrogens and alkylphenols in the area. (2) The levels of all phytoestrogens, in spring, and BPA, measured in autumn, attained at some locations high levels, which in association with other compounds present in this estuary are reportedly hazardous for the environment. (3) As to seasonal fluctuations, the phytoestrogens rose continuously from winter to spring, at which the total joint concentration of DAID, GEN and BIO-A attained levels up to $1.1 \mu \mathrm{g} / \mathrm{L}$, an estrogenic load that, facing the literature, may cause endocrine disruption in fish. In summer, none of the assayed EDCs was found, suggesting that biodegradation might have occurred stimulated by the high temperatures and the presence of the adequate $\mathrm{pH}$ values. In autumn, high levels of BPA were found in most studied zones of the estuary. This suggests that the BPA input occurs, despite not all over the year. (4) All measured phytoestrogens, and also BPA, showed a concentration gradient that, in general, decreased towards the sea. However, tides did not have a major impact in the measured concentrations. (5) This study did not demonstrated clear "hot spots" for EDCs in the estuary, despite the total load of estrogenic EDCs was greater at the S8 station.

Acknowledgements This study was financially supported by the Fundação para a Ciência e Tecnologia - FCT (PhD Grant SFRH/BD/18231/2004/SLU, attributed to Cláudia Ribeiro), and by the Cooperativa de Ensino Superior, Politécnico e Universitário, CRL (CESPU)/ISCS-N (Research Projects 1F/ 13/2005/CESPU and 2F/02/2006/CESPU). 


\section{References}

Ahel, M., Hrsak, D., \& Giger, W. (1994). Aerobic transformation of short-chain alkylphenol polyethoxylates by mixed bacterial cultures. Archives of Environmental Contamination and Toxicology, 26, 540-548.

Arvanitidou, M., Kanellou, K., \& Vagiona, D. G. (2005). Diversity of Salmonella spp. and fungi in northern Greek rivers and their correlation to fecal pollution indicators. Environmental Research, 99, 278-284.

Bacelar-Nicolau, P., Nicolau, L. B., Marques, J. C., Morgado, F., Pastorinho, R., \& Azeiteiro, U. M. (2003). Bacterioplankton dynamics in the Mondego estuary (Portugal). Acta Oecologica - International Journal of Ecology, 24, S67-S75.

Baeta, A., Cabral, H. N., Neto, J. M., Marques, J. C., \& Pardal, M. A. (2005). Biology, population dynamics and secondary production of the green crab Carcinus maenas (L.) in a temperate estuary. Estuarine Coastal and Shelf Science, 65, 43-52.

Ballesteros, O., Zafra, A., Navalon, A., \& Vilchez, J. L. (2006). Sensitive gas chromatographic-mass spectrometric method for the determination of phthalate esters, alkylphenols, bisphenol $\mathrm{A}$ and their chlorinated derivatives in wastewater samples. Journal of Chromatography A, 1121, 154-162.

Beck, I. C., Bruhn, R., Gandrass, J., \& Ruck, W. (2005). Liquid chromatography-tandem mass spectrometry analysis of estrogenic compunds in coastal surface water of the Baltic Sea. Journal of Chromatography A, 1090, 98-106.

Booth, N. L., Overk, C. R., Yao, P., Totura, S., Deng, Y., Hedayat, A. S., et al. (2006). Seasonal variation of red clover (Trifolium pratense L., Fabaceae) isoflavones and estrogenic activity. Journal of Agricultural and Food Chemistry, 54, 1277-1282.

Cardoso, P. G., Pardal, M. A., Raffaelli, D., Baeta, A., \& Marques, J. C. (2004). Macroinvertebrate response to different species of macroalgal mats and the role of disturbance history. Journal of Experimental Marine Biology and Ecology, 308, 207-220.

Chang, B. V., Chiang, F., \& Yuan, S. Y. (2005). Anaerobic degradation of nonylphenol in sludge. Chemosphere, 59, 1415-1420.

Coelho, A. C., Fontaínhas-Fernandes, A., Santos, A., Cortes, R., \& Rodrigues, J. (2003). Mucormycosis due to Rhizopus sp. in fishes: first case described in Portugal. Arquivo Brasileiro Medicina Veterinária e Zootecnia, 55, 234-237.

Diez, S., Lacorte, S., Viana, P., Barcelo, D., \& Bayona, J. M. (2005). Survey of organotin compounds in rivers and coastal environments in Portugal 1999-2000. Environmental Pollution, 136, 525-536.

Ferreira, S. M., Pardal, M. A., Lillebo, A. I., Cardoso, P. G., \& Marques, J. C. (2004). Population dynamics of Cyathura carinata (Isopoda) in a eutrophic temperate estuary. Estuarine Coastal and Shelf Science, 61, 669-677.

Fossi, M. C., Casini, S., Marsili, L., Ancora, S., Mori, G., Neri, G., et al. (2004). Evaluation of ecotoxicological effects of endocrine disrupters during a four-year survey of the Mediterranean population of swordfish (Xiphias gladius). Marine Environmental Research, 58, 425-429.
International Conference on Harmonisation (ICH) (1996). Validation of analytical procedures: Methodology, Q2B (CPMP/ICH/281/96). London: The European Agency for the Evaluation of Medicinal Products.

Jobling, S., Beresford, N., Nolan, M., Rodgers-Gray, T., Brighty, G. C., Sumpter, J. P., et al. (2002). Altered sexual maturation and gamete production in wild roach (Rutilus rutilus) living in rivers that receive treated sewage effluents. Biology of Reproduction, 66, 272-281.

Jobling, S., Tyler, C. R., Sumpter, J. P., Nolan, M., \& Brighty, G. (1998). Widespread sexual disruption in wild fish. Environmental Science and Technology, 32, 2498-2506.

Kang, J. H., \& Kondo, F. (2005). Bisphenol A degradation in seawater is different from that in river water. Chemosphere, 60, 1288-1292.

Kiparissis, Y., Balch, G. C., Metcalfe, T. L., \& Metcalfe, C. D. (2003). Effects of the isoflavones genistein and equol on the gonadal development of Japanese medaka (Oryzias latipes). Environmental Health Perspectives, 111, 1158-1163.

Lee, S. H., Jung, B. H., Kim, S. Y., \& Chung, B. C. (2004). Determination of phytoestrogens in traditional medicinal herbs using gas chromatography-mass spectrometry. Journal of Nutritional Biochemistry, 15, 452-460.

Liggins, J., Mulligan, A., Runswick, S., \& Bingham, S. A. (2002). Daidzein and genistein content of cereals. European Journal of Clinical Nutrition, 56, 961-966.

Lillebo, A. I., Neto, J. M., Martins, I., Verdelhos, T., Leston, S., Cardoso, P. G., et al. (2005). Management of a shallow temperate estuary to control eutrophication: The effect of hydrodynamics on the system's nutrient loading. Estuarine Coastal and Shelf Science, 65, 697-707.

Lopes, R. J., Pardal, M. A., \& Marques, J. C. (2000). Impact of macroalgal blooms and wader predation on intertidal macroinvertebrates: Experimental evidence from the Mondego estuary (Portugal). Journal of Experimental Marine Biology and Ecology, 249, 165-179.

Mills, L. J., \& Chichester, C. (2005). Review of evidence: Are endocrine-disrupting chemicals in the aquatic environment impacting fish populations? Science of the Total Environment, $343,1-34$.

Pereira, P., Vale, C., Ferreira, A. M., Pereira, E., Pardal, M. A., \& Marques, J. C. (2005). Seasonal variation of surface sediments composition in Mondego River estuary. Journal of Environmental Science and Health, 40, 317-329.

Quintana, J. B., Carpinteiro, J., Rodriguez, I., Lorenzo, R. A., Carro, A. M., \& Cela, R. (2004). Determination of natural and synthetic estrogens in water by gas chromatography with mass spectrometric detection. Journal of Chromatography $A, 1024,177-185$.

Ribeiro, C., Tiritan, M. E., Rocha, E., \& Rocha, M. J. (2007). Development and validation of a HPLC-DAD method for determination of several endocrine disrupting compounds in estuarine water. Journal of Liquid Chromatography and Related Sciences, 30, 2729-2746.

Santos, S., Figueiredo-Fernandes, A., Monteiro, S. M., Oliveira, S., Cortes, R., \& Fontaínhas-Fernandes, A. A. (2002). Análise histológica das alterações do tecido hepático da boga (Chondrostoma polylepis polylepis) na Bacia do Mondego. In: R. P. d. Zootecnia (Ed.), X Congresso de Zootecnia, pp. 522-526. 
Shareef, A., Angove, M. J., \& Wells, J. D. (2006). Optimization of silylation using $\mathrm{N}$-methyl-N-(trimethylsilyl)-trifluoroacetamide, N,O-bis-(trimethyl.silyl)-trifluoroacetamide and N(tert-butyldimethylsilyl)-N-methyltrifluoroacetamide for the determination of the estrogens estrone and 17 alphaethinylestradiol by gas chromatography-mass spectrometry. Journal of Chromatography A, 1108, 121-128.

Silveira, M. (2007). Identification of endocrine disruptors in superficial waters of Douro River estuary. Dissertation, University of Porto, Portugal.

Sohoni, P., Tyler, C. R., Hurd, K., Caunter, J., Hetheridge, M., Williams, T., et al. (2001). Reproductive effects of long-term exposure to bisphenol a in the fathead minnow (Pimephales promelas). Environmental Science \& Technology, 35, 29172925.

Staples, C. A., Woodburn, K., Caspers, N., Hall, A. T., \& Klecka, G. M. (2002). A weight of evidence approach to the aquatic hazard assessment of bisphenol A. Human and Ecological Risk Assessment, 8, 1083-1105.

Vethaak, A. D., Lahr, J., Schrap, S. M., Belfroid, A. C., Rijs, G. B. J., Gerritsen, A., et al. (2005). An integrated assessment of estrogenic contamination and biological effects in the aquatic environment of The Netherlands. Chemosphere, 59, 511-524. 